\title{
Research on Innovation and Entrepreneurship Education of University Students in Zhejiang Province*
}

\author{
Keqing Du \\ Jiaxing University \\ Jiaxing, China \\ Yingjie Chen \\ Jiaxing University \\ Jiaxing, China \\ Yuyou Guo \\ Jiaxing University \\ Jiaxing, China
}

\author{
Wenhong Cheng** \\ Jiaxing University \\ Jiaxing, China \\ **Corresponding Author
}

\author{
Xin Zhou \\ Jiaxing University \\ Jiaxing, China \\ Weihan $\mathrm{Xu}$ \\ Jiaxing University \\ Jiaxing, China
}

\begin{abstract}
In this paper, the present situation of college students' demand and recognition for innovation and entrepreneurship education is obtained through the research of six colleges in Zhejiang Province and by using statistical software to analyze the data. And the present situation in Zhejiang Province is compared with the European and American countries. With the knowledge age, entrepreneurship education for college students has increasingly become the direction of higher education reform in the world. Entrepreneurship education in Europe and America universities has accumulated rich experience in their long-term exploration. But China's entrepreneurship education is in the initial stage, and there is no complete theoretical system of entrepreneurship education. And the biggest problem is the lack of recognition and demand of college students for innovation and entrepreneurship education. On the basis of summing up the successful experience of foreign countries and the actual situation of Zhejiang Province which is the large educational province in China, this paper puts forward some reasonable suggestions on improving the demand and recognition of college students for innovation and entrepreneurship education and perfecting the theoretical system of entrepreneurship education.
\end{abstract}

Keywords-Zhejiang Province; colleges and universities; innovation and entrepreneurship; education; recognition; knowledge degree

\section{INTRODUCTION}

\section{A. Background}

With the continuous development of China's educational

*2017 Zhejiang Academic Science and Technology Innovation Activity \& New Seeded Talent Plan' Funding Project (Project No.:2017R417033) system reform, the higher education mode has gradually been changed from elite education to popularization. Fronting the severe employment situation of college students, a large percentage of contemporary college students choose innovation and entrepreneurship. Entrepreneurship education has been implemented in China for nearly 30 years, which has been recognized gradually from university to society and become one of the most important forms of higher education in China. But compared with the superior policy environment and attention provided by Britain, Germany, Japan and Singapore for innovation and entrepreneurship education in colleges and universities, there are many problems in China's entrepreneurial innovation projects. Above all, the low recognition and demand of entrepreneurship education is one of most important problems.

\section{B. Research Significance}

In recent years, Zhejiang has implemented a number of initiatives and policies to promote the implementation of innovation and entrepreneurship education in universities. In 2015, the General Office of Zhejiang Provincial Government issued opinions on speeding up the development of maker space and promoting innovation and entrepreneurship. And it is necessary to further optimize the environment for innovation and entrepreneurship and stimulate the creativity of the whole society. The basic connotation of innovation and entrepreneurship education is to develop and improve the innovative spirit and quality of students, namely, to cultivate the enterprising spirit, career and pioneering spirit of college students, and to improve the students' ability to plan business activities and engage in a certain career planning. The development of college students' new entrepreneurship 
education is of great significance for improving the national entrepreneurial level and innovation ability, strengthening the practical ability of college students and the ability of knowledge transformation, and solving the problem of "difficult employment" for college students.

\section{Research at Home and Abroad}

1) Domestic situation of innovation and entrepreneurship education recognition: Innovation and entrepreneurship education in colleges and universities has become a new topic in the educational field at home and abroad. According to the literature of innovation and entrepreneurship education, it is found that the research trend of college students' innovation and entrepreneurship education at home has the following several common characteristics:

- The existing literature and research mainly shows that the domestic universities have not formed a complete theoretical system of entrepreneurship education through comparing the domestic and foreign innovation and entrepreneurship educations. But overseas entrepreneurship education in colleges and universities has accumulated rich experience in their long-term exploration. For example, Wang Guilin and Yang Zhiqiang[1] summed up the experience of development of entrepreneurship education in the United States and Japan, which requires that the entrepreneurship education in colleges and universities should be guided by the advanced ideas, with the system of cooperation between government, industries and colleges, and based on scientific and technological content. Huang Zhaoxin, Wang Zhiqiang [2], after comparing with the UK, concluded that the entrepreneurship education in Chinese colleges and universities should change the ""thousand a voice" situation based on the integration of our own school characteristics and professional education.

- Professionalization refers that entrepreneurship education in colleges and universities should have exclusive disciplines, expert teams and professional education methods. There are three difficulties in front of the professionalization of innovation and entrepreneurship: One is the lack of discipline support, two is the lack of expert teams, and three is the lack of professional education methods. Sun Yue[3] believes that Chinese innovation and entrepreneurship education should be deepened with education and teaching reform and by improving the quality of education evaluation system; Zhuang Yimin[4] pointed out the present situation of local colleges and universities entrepreneurship at the present stage: students' understanding of entrepreneurship is broad, and their concern for entrepreneurship education is not high; the quality of entrepreneurship education in colleges is not high with a relatively simple mode. Tang Li and Zhou Yang[5] point out that the problem of innovation and entrepreneurship education in China lies in the lack of scientific concept of entrepreneurship education, and the lack of a reasonable system of entrepreneurship teaching, including the limited number of teachers, not high degree of specialization, unreasonable compiling of teaching materials and backward teaching methods. Liu Yushan[6] believes that the most important thing for domestic innovation and entrepreneurship education is to deepen the understanding of entrepreneurship education and to improve the atmosphere of it.

- Integration refers to the integration of education and teaching in entrepreneurship education in colleges and universities, with the integration of employment and entrepreneurship education and the school and outschool education. At present, there are three main problems: one is that the cohesion of education and teaching is not strong, the curriculum system of entrepreneurship education is not perfect, the classroom teaching and entrepreneurial activities are not planned as a whole, and the theoretical learning and practice training fail to promote each other; two, the synergy of employment and entrepreneurship education is not strong, and entrepreneurship education and employment education should be coordinated; three, the linkage between school and out of school education is not strong, and the entrepreneurship education should realize the organic integration of university talent training, teaching and research, enterprise capital technology and production practice. Zhu Keyi [7] believes that the construction of entrepreneurship education curriculum system needs three parts, namely, teachers, social enterprises and government policies. For theses, it is necessary to attach great importance to teacher training, strengthen joint training with society, enterprises and factories, develop double-teacher type tutors, and actively cooperate with senior entrepreneurs with rich practical experience in the industry. Yue Sun [3] believes that it is necessary to build a three-in-one entrepreneurship education platform. First of all, to increase the sense of community's recognition of entrepreneurship. Secondly, to strengthen the cooperation between school and enterprise, and carry out the education of entrepreneurship with universities. The most important thing is to improve the supporting policy for entrepreneurship and connect the support of all sectors of society.

In conclusion, on the basis of the existing research, we must start with the three aspects of professionalization, integration and scientization to promote the recognition and demand of college students for innovation and entrepreneurship education. Yang Juan's college innovative education can effectively cultivate educator's entrepreneurial knowledge and ability. Therefore, enhancing students' recognition and demand of innovation and entrepreneurship education is of great significance to improve their ability.

2) Foreign situation of innovation and entrepreneurship Education: The research of innovation and entrepreneurship education in other countries shows that there is a close 
cooperation with government, industries and learning in Japan, its local economic development has local characteristics, and the key to success of entrepreneurship education in Japanese colleges and universities is to connect each other's entrepreneurship education in colleges and universities. In terms of entrepreneurship education curriculum models, there are different modes such as special entrepreneur education, entrepreneurial skills, comprehensive exercises and entrepreneurial spirit. Australian universities have also formed a mature and perfect structural system in entrepreneurship education, which have their own unique characteristics in the aspects of management system, practice teaching, curriculum construction, policy support and teacher staffing; they has three kinds of education modes: popularization mode, training mode and professional mode. At present, Nanyang Technology University is in the forefront of innovation and entrepreneurship education in the Asia Pacific region. Its establishment of school curriculum will help to solve the problems that need to be solved in the process of college students' entrepreneurship. On the one hand, we should try to use network simulation exercise in the course. On the other hand, the college students will direct go into the entrepreneurial environment and be provided with opportunities to communicate with the pioneers, the government, the ventures, the entrepreneurs and the intellectual property lawyers.

Stanford University is a role model in innovation and entrepreneurship education in colleges and universities, which regards cultivating the innovative spirit of teachers and students as an important mission. Massachusetts Institute of Technology has created an innovative and entrepreneurial mode integrating university, government and industry with high efficiency as guide, which is called the "three helix model". In this model, the school realizes the optimal combination of scientific research, practical application, teaching and school benefits. While the innovation and entrepreneurship education of Harvard University pays more attention to the practicality of teaching content and curriculum methods. It is found that, in the questionnaires distributed to the deans of 941 business schools in the United States, the most entrepreneurship courses offered by American colleges and universities are creating enterprises, small business management, business consulting, operation of new business, business plan writing, entrepreneurial financial management, identification of entrepreneurial opportunities and entrepreneurial marketing, which are only for undergraduates. According to the investigation, more than 3000 colleges in the world have set up more than 5200 entrepreneurship education courses, and have formed a relatively mature and perfect system of entrepreneurship education.

In conclusion, the overseas research on innovation and entrepreneurship education has a long history, and has made certain progress especially in the practical level. In addition, the well-known universities have achieved certain achievements, which are worth to learn from.

\section{QUESTIONNAIRE DESIGN}

The government and Zhejiang Province have issued a series of policies on innovation and entrepreneurship education in colleges and universities. Therefore, in order to get a more comprehensive understanding of development of education in innovation and entrepreneurship in colleges and universities, as well as a series of problems in the process of implementation, our group studied several universities in Zhejiang Province. In this study, we made a questionnaire survey on the status of innovation and entrepreneurship education implemented by our school students, and we also made interviews with some students and teachers and collected various materials. And the questionnaires designed for college students include 25 questions, such as the basic information of college students, the recognition and demand of innovation and entrepreneurship education, the establishment of curriculum system of innovation and entrepreneurship and the related reforms. Through the inquiry of information of the current situation of innovation and entrepreneurship in universities and the collection of information on organizational management, the organizational management mode of innovation and entrepreneurship education in colleges and universities is understood.

Our questionnaire covers 211, 985 universities, provincial key universities, ordinary universities, private colleges and other major institutions, including Zhejiang University, Hangzhou Normal University, Zhejiang Gongshang University, China Academy of Art, Ningbo University, Ningbo Dahongying University and so on. And the students' grades and majors are also different, in which the grades are mainly juniors and seniors, accounting for $77.1 \%$ of the total students; and the majors are mainly in economics and management, literature, history, philosophy and arts, accounting for $77.2 \%$ of the total students. Sample information

According to the phased research results, 400 questionnaires were distributed to 6 universities (Zhejiang University, Hangzhou Normal University, China Academy of Art, Zhejiang Gongshang University, Ningbo Dahongying University and Ningbo University) in Hangzhou, Zhejiang Province, and 360 copies were effectively recovered, with a $80 \%$ recovery rate. In the results we collected, there are 113 men students and 127 women students in 240 people surveyed, with a nearly $1: 1$ survey scale. And the sample covers $22.9 \%$ of sophomores, $65 \%$ of juniors and $12.1 \%$ of senior graduates, and most of them are junior students. In addition, the sample also includes 5 types of majors, $49.6 \%$ of economics and management, $15 \%$ of science and technology, $27.6 \%$ of literature, history, philosophy and arts, $7.1 \%$ of education and $0.8 \%$ of law. The specific data are in "Table I": 
TABLE I.

BASIC INFORMATION OF COLLEGE STUDENTS

\begin{tabular}{l|l|c|c}
\hline \multicolumn{2}{l|}{} & $\begin{array}{c}\text { Number of } \\
\text { People }\end{array}$ & $\begin{array}{c}\text { Percentage } \\
(\%)\end{array}$ \\
\hline \multirow{5}{*}{ Sex } & Male & 113 & 47.1 \\
& Female & 127 & 52.9 \\
\hline \multirow{5}{*}{ Schade } & Sophomore & 55 & \\
& Junior & 156 & 22.9 \\
& Senior & 29 & 65.0 \\
& Zhejiang University Hangzhou & 60 & 12.1 \\
& Normal University, & 60 & 16.7 \\
& China Academy of Art & 60 & 16.7 \\
& Zhejiang Gongshang University & 60 & 16.7 \\
& Ningbo Dahongying University & 60 & 16.7 \\
& Ningbo University & 60 & 16.7 \\
\hline \multirow{5}{*}{ Major } & Economics and Management & 119 & 49.6 \\
& Science and Engineering & 36 & 15.0 \\
& Agriculture Cure & 0 & 0.0 \\
& Literature, History, Philosophy & 66 & 27.5 \\
& and Arts & 17 & 7.1 \\
& Education & 2 & 0.8 \\
& Law & 0 & 0.0 \\
\hline & Others &
\end{tabular}

A. Knowledge Status of College Students for Innovation and Entrepreneurship Education

In 2017, the government and Zhejiang Province issued a series of relevant policies and regulations to support college students' entrepreneurship. So we conducted a survey of students' recognition of these policies. In the results, $7.5 \%$ of the students are very familiar with the policy of "entrepreneurship education is included in credit management", $48.3 \%$ of the students know the policy well, and $27.1 \%$ of the students know it. Si it can be seen from the side that these six universities have done a good job of including entrepreneurship education into credit management, and this policy has a high degree of knowledge among students. For the policies of "system of simplifying the enterprise registration ", "entrepreneurial social security subsidies", "promoting", "profession + entrepreneurship", most of the students are focused on not knowing much and not knowing. It can be seen that in the three policies, most of students expressed their knowing or not knowing much, and few of them knew much about these policies. For the policy of "starting training project of entrepreneurship mentor, coordinating resources to set up venture capital fund for college students", $54.6 \%$ of them do not know much and do not know it. Similarly, for the policy of "the college students who are lack of venture capital can apply for a loan no more than 300,000 Yuan", 54.6\% of them do not know much and do not know it. For the policy of "the university graduates who establish individual business and individual proprietorship enterprises can enjoy the tax reduction and remission policy according to law", $30.4 \%$ of the students know it, and $35 \%$ of the students do not know much, $19.6 \%$ of the students do not know it. The details are shown in "Fig. 1" and "Table II".
TABLE II. CORRESPONDENCE TABLE OF OPtiONS

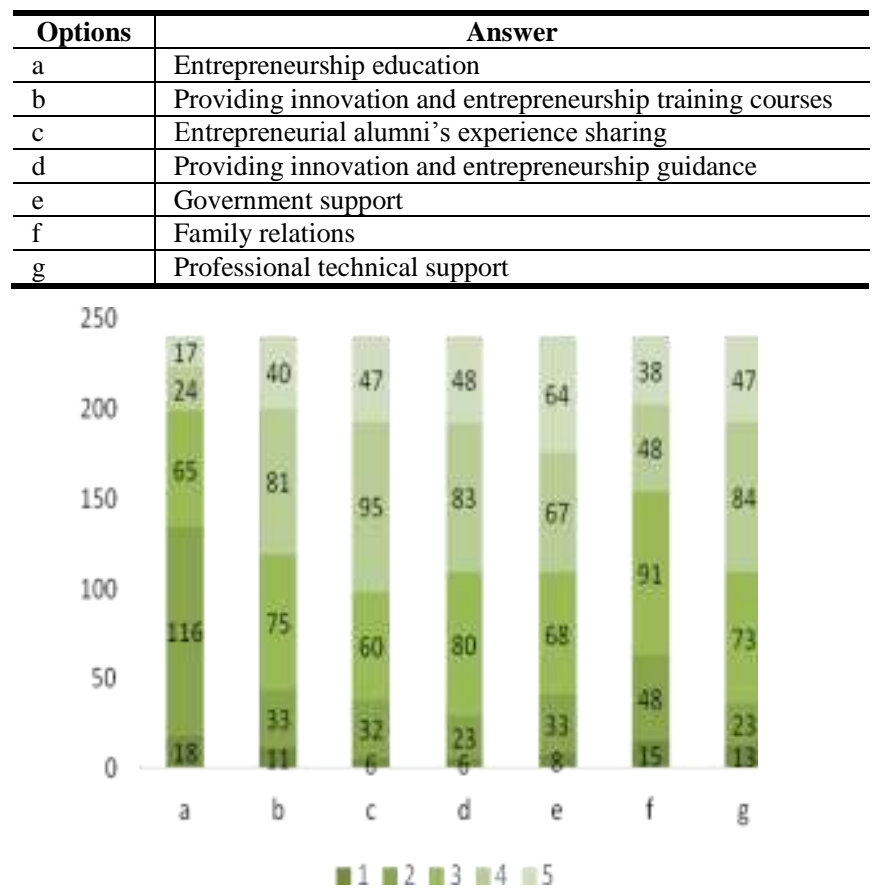

Fig. 1. Knowledge Status about Policies.

For the policies, it can be seen that more students say that they do not know much or do not know about these policies, which shows that students from six universities have little knowledge of innovation and entrepreneurship education, and the implementation strength of these policies is too small to fully introduce innovation and entrepreneurship education to students. As a result, students have little knowledge of innovation and entrepreneurship education and are unable to do a series of innovative and entrepreneurial work on their own.

\section{B. Thoughts about Entrepreneurship}

Based on the understanding of the students' willingness to start a business, we made a survey to the students in order to understand the students' interest in innovative entrepreneurship and the future direction of development. Among the respondents, $32.10 \%$ of the students expressed their interests, depending on the situation; $21.7 \%$ of the students said they were ready to start a business.; $17.9 \%$ of the students said they did not plan it; $28.3 \%$ of the students said they were only interested in and waiting and seeing. On the whole, although $53.8 \%$ of the students expressed their interests in entrepreneurship, almost half of them still had a wait-and-see attitude towards entrepreneurship. This indicates that many college students still want to start a business, and that innovation and entrepreneurship are accepted by more and more students. With the increase of demand, the popularization of innovation and entrepreneurship education will be increased, so that students need to know more about the knowledge and policies of innovation and entrepreneurship education and lay a solid foundation for future career planning. It is necessary to intensify the 
publicity of innovation and entrepreneurship education and provide guidance to correct outlook on life, values and world outlook. The details are shown in "Fig. 2".

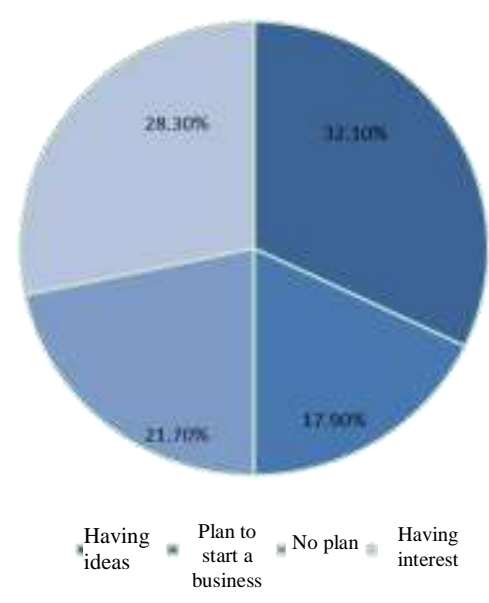

Fig. 2. Entrepreneurial intention map.

\section{Effective Measures Taken for Innovation and Entrepreneurship Education in Universities}

In the reform of innovation and entrepreneurship education system, various colleges have provided diversified support to college students, and adopted various and multichannel measures. We can find that the six colleges have carried out innovative and entrepreneurial theory courses, set up innovative entrepreneurship clubs, innovation and entrepreneurship information exchange platforms, school and enterprise cooperation innovation and entrepreneurship education base, and other measures. And the riches of knowledge and the continuous promotion of communication will help students to enhance their recognition and demand for innovation and entrepreneurship.

In different schools, there are some differences in the recognition of the measures for students taken by the colleges. In China Academy of Art and Zhejiang Gongshang University, the students generally have higher recognition and awareness of the measures adopted taken by their college. While in Zhejiang University, Hangzhou Normal University and Zhejiang Gongshang University, the students' degree of awareness of the measures taken by the colleges is mainly based on curriculum development, creation of innovation and entrepreneurship clubs, and information communication platforms; in the measures taken by China Academy of Art and Ningbo Dahongying University, innovation and entrepreneurship tutor tracking is relatively degree of knowledge among students; for the measures taken by Zhejiang Gongshang University, the knowledge degree of establishment of the innovation and entrepreneurship clubs is 95\%, which shows that Zhejiang Gongshang University has made some progress and achievements in the work of innovation and entrepreneurship in the clubs, and a great number of students have learned that. During promoting the reform of innovation and entrepreneurship education system, these colleges have also adopted new and attractive measures for students, such as: innovation and entrepreneurship tutor tracking, establishment of business incubators for undergraduates, and carrying out diversified competitions on innovation and entrepreneurship. The details are in "Table III".

TABLE III. CORRESPONDING MEASURes TAKEn by COLLEGES

\begin{tabular}{|c|c|c|c|c|c|c|}
\hline & $\begin{array}{c}\text { Zhejiang } \\
\text { University }\end{array}$ & $\begin{array}{c}\text { Hangzhou } \\
\text { Normal } \\
\text { University } \\
\end{array}$ & $\begin{array}{l}\text { China Academy } \\
\text { of Art }\end{array}$ & $\begin{array}{c}\text { Zhejiang } \\
\text { Gongshang } \\
\text { University }\end{array}$ & $\begin{array}{c}\text { Ningbo } \\
\text { Dahongying } \\
\text { University }\end{array}$ & $\begin{array}{l}\text { Ningbo } \\
\text { University }\end{array}$ \\
\hline Innovation and entrepreneurship theory course & 0.45 & 0.73 & 0.50 & 0.52 & 0.61 & 0.54 \\
\hline Innovation and entrepreneurship lecture & 0.38 & 0.65 & 0.47 & 0.45 & 0.52 & 0.42 \\
\hline Innovation and entrepreneurship tutor tracking & 0.48 & 0.22 & 0.52 & 0.47 & 0.53 & 0.44 \\
\hline Entrepreneurship training software & 0.50 & 0.00 & 0.45 & 0.43 & 0.34 & 0.23 \\
\hline Innovation and entrepreneurship club & 0.43 & 0.63 & 0.65 & 0.95 & 0.57 & 0.45 \\
\hline $\begin{array}{llll}\begin{array}{l}\text { Competition of } \\
\text { entrepreneurship }\end{array} & \text { innovation } & \text { and } \\
\end{array}$ & 0.33 & 0.68 & 0.43 & 0.43 & 0.54 & 0.67 \\
\hline $\begin{array}{l}\text { Communication platform of innovation and } \\
\text { entrepreneurship }\end{array}$ & 0.60 & 0.85 & 0.68 & 0.72 & 0.62 & 0.74 \\
\hline Business incubator & 0.07 & 0.58 & 0.45 & 0.42 & 0.51 & 0.12 \\
\hline $\begin{array}{l}\text { Education base for cooperation of school, } \\
\text { government and enterprise }\end{array}$ & 0.13 & 0.63 & 0.42 & 0.37 & 0.43 & 0.34 \\
\hline Not implemented & 0.00 & 0.00 & 0.38 & 0.32 & 0.00 & 0.00 \\
\hline Not known & 0.07 & 0.38 & 0.37 & 0.25 & 0.12 & 0.05 \\
\hline
\end{tabular}

\section{Different Demands of College Students for Different} Education Resources of Innovation and Entrepreneurship

According to the survey, it is found that college students' demand for environmental resources is mainly the following five aspects: innovation and entrepreneurial practice base, innovation and entrepreneurship training course, entrepreneurial alumni experience sharing, financial support, financing channels. The proportion of college students who demands innovation and entrepreneurial practice base and entrepreneurial alumni experience sharing is relatively high, occupying $25.4 \%$ and $22.5 \%$ respectively. The enrichment of practice bases helps students to apply their knowledge rationally for practice, and the students will get real knowledge and learn more experience in practice. The survey shows that $42.1 \%$ of the college students really need innovative and entrepreneurial training courses provided colleges, and nearly half of the students show a higher degree 
of demand for it. The period when the students are in colleges is a process of absorbing knowledge continuously. The accumulation of knowledge about innovation and entrepreneurship is an important prerequisite for innovation and entrepreneurship. And the experience sharing of entrepreneurial alumni can also bring experience to contemporary college students who want to do innovation and entrepreneurship, which can let each other collide with the spark of thought, stimulate college students' enthusiasm for innovation and entrepreneurship, and encourage college students to innovate and start their own businesses independently. Thus we can find that college students generally need more knowledge about innovation and entrepreneurship, and the sufficient knowledge reserves will create a solid foundation for the future path of entrepreneurship. The number of students needing capital support resources reached $45.4 \%$. At the same time, the number of students needing financing channels was $31.7 \%$. Therefore, it is easy to know that most of the students think that the realization of innovation and entrepreneurship cannot be separated from the supply of funds. And the continuous supply of funds and the rich and diversified financing channels will provide great convenience for the realization of innovation and entrepreneurship. The details are shown in "Fig. 3" and "Table IV".

TABLE IV.

CORRESPONDENCE TABLE OF OPTIONS

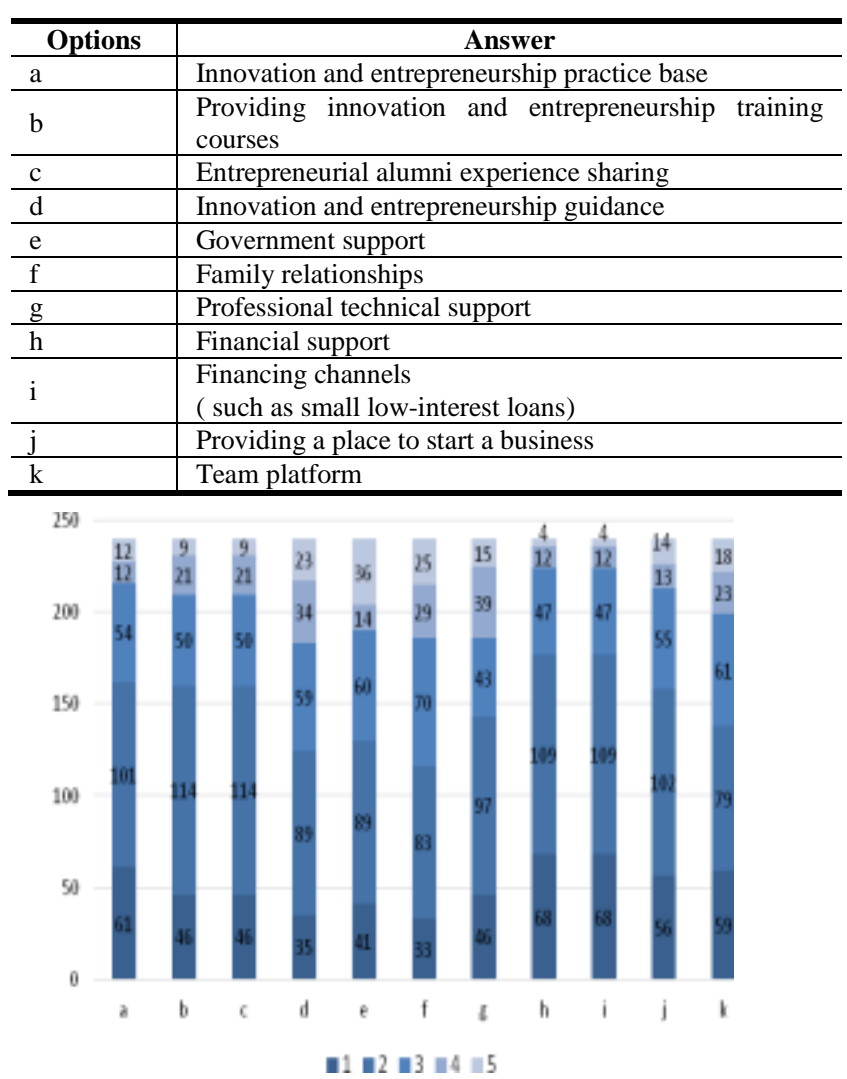

Fig. 3. Degrees of Resource Demand.
Degree of Satisfaction of University Innovation and Entrepreneurship

Through the students' satisfaction with the various resources of colleges, a cross contingency analysis was conducted in the colleges. First of all, for the colleges' "business project application evaluation management process", the chi square is $0.001<0.05$, that is to reject the original hypothesis, so the colleges and this project has a correlation in "Table V".

TABLE V. ChI-SQuARE TeSt SheET

\begin{tabular}{l|l|l|l}
\hline & Value & $\begin{array}{c}\text { Degree of } \\
\text { Freedom }\end{array}$ & $\begin{array}{c}\text { Asymptotic } \\
\text { Significance } \\
\text { (Bidirectional) }\end{array}$ \\
\hline Pearson Chi-Square & $31.946^{\mathrm{a}}$ & 12 & 0.001 \\
\hline Likelihood ratio (L) & 32.246 & 12 & 0.001 \\
\hline Valid case number & 240 & & \\
\hline
\end{tabular}

a. a. Four cells $(20.0 \%)$ have an expected count of less than 5 . The minimum expected count is 4.25 .

Through the cross table, we can see that for the evaluation management process of application and implementation of entrepreneurial projects, in Zhejiang University the number of people who are very satisfied with it is only 7, while the number of people who are fairly satisfied and satisfied is the majority with 40 people. The same situation also appeared in Hangzhou Normal University and Zhejiang Gongshang University, indicating that the three colleges lack of enough strength in this option. But in the China Academy of Art, the number of people who expressed satisfaction and fairly satisfaction with it accounted for the majority, a total of 42 . The students of Ningbo Dahongying University and Ningbo University feel satisfied with what their college has done on this project. It shows that the China Academy of Art has slightly higher than the other 5 schools in the project management process of innovation and entrepreneurship education. The details are shown in "Table VI". 


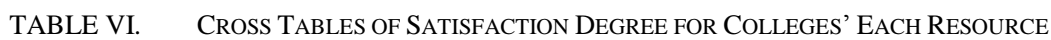

\begin{tabular}{|c|c|c|c|c|c|c|}
\hline & & \multicolumn{5}{|c|}{$\begin{array}{l}\text { Evaluation Management Process of Application and Implementation of } \\
\text { Entrepreneurial Projects }\end{array}$} \\
\hline & & Very satisfied & Fairly satisfied & Less satisfied & Very dissatisfied & Unclear \\
\hline \multirow{6}{*}{ Colleges } & Zhejiang University & 7 & 23 & 17 & 9 & 8 \\
\hline & Hangzhou Normal University & 10 & 12 & 21 & 9 & 2 \\
\hline & China Academy of Art & 17 & 25 & 13 & 3 & 3 \\
\hline & Zhejiang Gongshang University & 5 & 22 & 28 & 2 & 3 \\
\hline & Ningbo Dahongying University & 7 & 23 & 17 & 9 & 4 \\
\hline & Ningbo University & 18 & 20 & 19 & 2 & 1 \\
\hline \multicolumn{2}{|l|}{ Total } & 64 & 125 & 112 & 34 & 23 \\
\hline
\end{tabular}

For "guidance from the entrepreneurship instructors", it is obvious that more than half of people in Zhejiang University are satisfied with this option; while in Zhejiang Gongshang University and Hangzhou Normal University, most of the students chose to be satisfied, which indicates that the guidance of entrepreneurship instructors on students' innovation and entrepreneurship is not particularly enough. The students from China Academy of Art said they were fairly satisfied with the project. For the item-by-item comparison of the six colleges, the per capita is gathered in the "Fairly satisfied" and "Satisfied", which shows that there are special entrepreneurship instructors in each university to follow up the students' innovation and entrepreneurship process, but the strength of each school is slightly different. The specific situation is in "Table VII":

TABLE VII. Cross Tables of SATISFACtion Degree For Colleges' Each Resource

\begin{tabular}{|c|c|c|c|c|c|c|}
\hline & & \multicolumn{5}{|c|}{ Guidance from the Entrepreneurship Instructors } \\
\hline & & Very satisfied & Fairly satisfied & \begin{tabular}{|l|} 
Less satisfied \\
\end{tabular} & Very dissatisfied & Unclear \\
\hline \multirow{6}{*}{ Colleges } & Zhejiang University & 12 & 20 & 21 & 7 & 0 \\
\hline & Hangzhou Normal University & 5 & 11 & 35 & 7 & 2 \\
\hline & China Academy of Art & 11 & 30 & 7 & 10 & 2 \\
\hline & Zhejiang Gongshang University & 10 & 13 & 19 & 8 & 10 \\
\hline & Ningbo Dahongying University & 5 & 17 & 31 & 5 & 2 \\
\hline & Ningbo University & 6 & 33 & 19 & 2 & 0 \\
\hline \multicolumn{2}{|l|}{ Total } & 49 & 124 & 132 & 39 & 16 \\
\hline
\end{tabular}

For the "college financial support", 53 students in Zhejiang University were satisfied" or above. It can be seen that in students' innovation and entrepreneurship education, Zhejiang University provides students with abundant financial support to ensure students' innovation and entrepreneurship activities. In the rest of five schools, the students believe that the school's financial support for innovation and entrepreneurship is not completely able to keep up with the needs and is only in a "Satisfied" or "Fairly satisfied" stage. Looking at the data, respondents from these colleges are more dissatisfied with their financial support. And it is pointed out that colleges should also keep up with their financial support for students' innovation and entrepreneurship education, so as to meet the needs of students in this respect. The specific situation is in "Table VIII":

TABle VIII. C Cross Tables of Satisfaction Degree for Colleges’ Each Resource

\begin{tabular}{|c|c|c|c|c|c|c|}
\hline & & \multicolumn{5}{|c|}{ College Financial Support } \\
\hline & & Very satisfied & Fairly satisfied & Less satisfied & Very dissatisfied & Unclear \\
\hline \multirow{6}{*}{ Colleges } & Zhejiang University & 12 & 20 & 21 & 5 & 2 \\
\hline & Hangzhou Normal University & 5 & 13 & 26 & 11 & 5 \\
\hline & China Academy of Art & 5 & 15 & 31 & 5 & 4 \\
\hline & Zhejiang Gongshang University & 2 & 14 & 35 & 6 & 3 \\
\hline & Ningbo Dahongying University & 0 & 12 & 39 & 8 & 1 \\
\hline & Ningbo University & 9 & 35 & 12 & 2 & 2 \\
\hline Total & & 33 & 119 & 164 & 37 & 17 \\
\hline
\end{tabular}

Most of the students from six colleges are satisfied with the "innovation and entrepreneurship type" and "sites support (maker bar)". It shows that these colleges do well in the types of innovation and entrepreneurship education, and they can attract students' interest in various forms of innovation and entrepreneurship. And these colleges also pay more attention to the education of students' innovation and entrepreneurship, providing more convenient sites for students, and setting up a small communication site such as maker bar. It can better promote students' entrepreneurial ability and their understanding of innovation and entrepreneurship. The specific situation is in "Table. IX": 
TABle IX. Cross Tables of SAtisfaction Degree for Colleges’ Each Resource

\begin{tabular}{|c|c|c|c|c|c|c|}
\hline & & \multicolumn{5}{|c|}{ Innovation and Entrepreneurship Type } \\
\hline & & Very satisfied & Fairly satisfied & Less satisfied & Very dissatisfied & Unclear \\
\hline \multirow{6}{*}{ Colleges } & Zhejiang University & 3 & 19 & 32 & 5 & 1 \\
\hline & Hangzhou Normal University & 6 & 29 & 23 & 1 & 1 \\
\hline & China Academy of Art & 6 & 7 & 38 & 6 & 3 \\
\hline & Zhejiang Gongshang University & 3 & 18 & 29 & 4 & 6 \\
\hline & Ningbo Dahongying University & 1 & 18 & 37 & 5 & 0 \\
\hline & Ningbo University & 16 & 23 & 21 & 0 & 0 \\
\hline \multicolumn{2}{|l|}{ Total } & 35 & 114 & 180 & 20 & 11 \\
\hline
\end{tabular}

TABLE X. Cross Tables of Satisfaction Degree for Colleges' Each Resource

\begin{tabular}{|c|c|c|c|c|c|c|}
\hline & & \multicolumn{5}{|c|}{ Sites Support (Maker Bar) } \\
\hline & & Very satisfied & Fairly satisfied & Less satisfied & Very dissatisfied & Unclear \\
\hline \multirow{6}{*}{ Colleges } & Zhejiang University & 10 & 19 & 23 & 6 & 2 \\
\hline & Hangzhou Normal University & 5 & 15 & 28 & 7 & 5 \\
\hline & China Academy of Art & 12 & 33 & 10 & 3 & 2 \\
\hline & Zhejiang Gongshang University & 8 & 17 & 28 & 3 & 4 \\
\hline & Ningbo Dahongying University & 9 & 29 & 17 & 4 & 1 \\
\hline & Ningbo University & 14 & 19 & 26 & 0 & 1 \\
\hline \multicolumn{2}{|l|}{ Total } & 58 & 132 & 132 & 23 & 15 \\
\hline
\end{tabular}

\section{E. Conclusion}

First of all, the survey result shows that four colleges have done better in some aspects and not well in other aspects. But on the whole, they do well in the development of innovation and entrepreneurship education. In recent years, Zhejiang University has integrated innovation and entrepreneurship education into the whole process of talent training, around the national innovation driven development strategy and the requirements of building an innovation-originated nation, which have trained a large number of pioneering pioneers and models, formed a brand of innovation and entrepreneurship education with the characteristics of Zhejiang University, and built the Zijin Zhongchuang Small Town. In addition, it also has approved self-raised student support fund, docked various kinds of venture capital funds such as social angel investors, venture capital institutions and government, and set up more than 20 kinds of innovation and entrepreneurship scholarships. It has also become one of the demonstration points of national innovation and entrepreneurship education. Hangzhou Normal University accelerated the "business startups and innovation" education to speed up the talents training. 2 colleges and 5 professional groups are listed in the first batch of applied construction demonstration sites in Zhejiang Province. In June 2014, the entrepreneurship college was set up, which is featured by "Internet +". A college students' entrepreneurship park was established for students; and they cooperated with Alibaba Group to establish Alibaba business school, cooperated with Microsoft and IBM to set up the International Institute of Service Engineering. It is listed as one of the national innovation and entrepreneurship education demonstration sites. At the present stage, the China Academy of Art has already owned some college students' innovative and entrepreneurial incubator bases including Yuhang Dream Town, Jiangyunqi Town, Fuyang Gong Wang Art Garden and Mogan Mountain Music Gourd Park. And for the innovation and entrepreneurship education of the China Academy of Art, its guiding and supporting the outstanding entrepreneurial projects of college students rank top in China's art colleges. In
2009, Zhejiang Gongshang University set up a business park for students' entrepreneurship. In addition, its supporting and guiding college students' entrepreneurship and cultivating entrepreneurial talents can make it more prominent in innovation and entrepreneurship education in the key universities in Zhejiang province.

Therefore, in general, in the six colleges that have been investigated, the innovation and entrepreneurship education has been done well. They can actively respond to the various innovative and entrepreneurial education policies of the state and Zhejiang Province on the basis of the actual conditions of China, and carry out the key innovation and entrepreneurship cultivation for college students.

\section{PROBLEMS IN IMPLEMENTING INNOVATION AND ENTREPRENEURSHIP EDUCATION IN COLLEGES AND UNIVERSITIES AND ANALYSIS OF CAUSES}

\section{A. Unclear Subject Orientation of Innovation and Entrepreneurship Education}

From the interview and the questionnaire, it can be seen that most of the students in colleges have participated in the training of innovative and entrepreneurial education which appears in a series of lectures or elective courses, such as "college career planning", "college employment guidance", etc. And few students will regard innovation education as their own major courses. It is also found that at present, the students in colleges are not clear about the goal of innovation and entrepreneurship, and more are hoping to achieve their own interests through entrepreneurship, not an increase in their own experience or resume. What is more, nowadays, people regard innovation and entrepreneurship as a way to relieve the pressure of employment. Through our investigation, it can be concluded that the colleges do not make a clear plan for the innovation and entrepreneurship education curriculum, and set up a suitable and systematic curriculum system for it. And it is not blended in the daily 
discipline education, which leads that many college students only pay attention to the learning of classroom knowledge and ignore their knowledge of innovation and entrepreneurship, so that they cannot truly integrate into the trend of "mass innovation ".

\section{B. Innovation and Entrepreneurship Education Lacking of Practical Links}

According to our survey data, there are roughly three types of innovation and entrepreneurship education in every major university. The first is to pay too much attention to the education of theory of innovation and entrepreneurship education; $57 \%$ of the respondents said that their college has carried out the curriculum of innovation and entrepreneurship theory, and $72 \%$ said their college had carried out lectures on innovation and entrepreneurship education. But at the same time, $64 \%$ believe that the integration of theoretical courses and practical courses is not high. It can be seen that most of them become formalistic, and students cannot learn moral things in theory in practice. The second is that schools have launched various entrepreneurial competitions at different extents, and set up innovative and entrepreneurial clubs. However, competitions and others are still limited to writing reports or on hand and oral, too superficial and lacking of substantive content. Third, some colleges and universities have added practical elements in the innovation and entrepreneurship education. For example, many colleges and universities have established college students' innovative business incubators, entrepreneurship parks and so on. But through our interview, we found that $69 \%$ of the respondents did not participate in practical activities, which also reflects that the forms of innovation and entrepreneurship education have not been popularized among college students.

At present, although a lot of colleges and universities have set up a business park, but these practice bases are more for the students who have entrepreneurial projects to use, many other majors' students do not participate in. For such students, there is no practice process, they cannot have a correct and profound cognition to innovation and entrepreneurship education, not to mention the demand for innovation and entrepreneurship education.

\section{Lack of a Good Social Entrepreneurial Environment}

Entrepreneurship education is now not simply the behavior of colleges, but also the result of joint efforts of the three parties of the government, society and colleges. From the perspective of current development, the southeast coastal cities in China have developed rapidly in recent years, and the entrepreneurial atmosphere in Jiangsu, Zhejiang and Shanghai is stronger than before. However, from the macro level, the overall entrepreneurial environment in our country is still not optimistic. Because of the shackles of conservative thoughts and traditional culture for thousands of years, there is a certain impact on the university graduates' entrepreneurship. From a microscopic level, even on the basis of Zhejiang's positive response to national policies, the implementation of policies by different colleges did not achieve the desired results. These policies are only temporary and not universal. We have not yet formed a set of policies and systems to support college students' entrepreneurship.

\section{CONCLUSION}

Through the questionnaire and interview survey of 6 universities in Zhejiang Province, we found and analyzed the status of innovation and entrepreneurship education in Zhejiang Province, and got enlightenment of education development in our province, compared the development of foreign innovation and entrepreneurship education. And the education countermeasures of innovation and entrepreneurship are proposed for reference.

\section{A. Grasping the Correct Education Concept of Innovation and Entrepreneurship}

In the new age of "mass innovation", innovation and entrepreneurship education is not only for the minority, but for all university graduates, so as to cultivate college students' ability of innovation and entrepreneurship education. Nowadays every major university should also change their concepts in time and accept the idea of innovation and entrepreneurship education, and no longer pay attention to the cultivation of cultural courses blindly, so that all students can truly accept the course of innovation and entrepreneurship education.

In the past, we understood the innovation and entrepreneurship education as an appropriate relief to employment pressure. Now we should understand the innovative and entrepreneurial education as a way to cultivate the students' innovative thinking and improve their entrepreneurial ability. We should also clarify the status of innovation and entrepreneurship education in higher education, and put the innovation and entrepreneurship education into practice. So that students can truly feel the existence of innovation and entrepreneurship education, and improve their entrepreneurial practice ability, which is good to cultivate real entrepreneurial talents.

\section{B. More Popular Innovation and Entrepreneurship Courses}

First, universities should combine practice with theory to make the courses more popular, change the innovation and entrepreneurship from "optional course" into "compulsory course" with the corresponding credits. Accordingly it no longer makes students feel that innovation and entrepreneurship education is a dispensable existence, so that students and teachers pay attention to the form of innovation and entrepreneurship education. The education shall be carried out to all the students not just a few students who have entrepreneurial intentions, so that every student will feel the charm of innovation and entrepreneurship through practice. Second, the beneficiaries of innovation and entrepreneurship education courses should be popularized. As stated above, every student should be involved in the course of innovation and entrepreneurship education. Through innovation and entrepreneurship education courses, we will further cultivate students' interest and the recognition and practical ability of innovation and entrepreneurship education. 


\section{Enriching Innovation and Entrepreneurship Practice Activities}

Many colleges have also opened a variety of innovation and entrepreneurship competitions, salon, and a lot of innovation and entrepreneurship practice bases. But from the present situation, the effect is not obvious. Therefore, colleges should rely on their existing resources for innovation and entrepreneurship education, such as innovation and business incubation base, Pioneer Park, etc. And it will more effectively provide technical guidance for students, so that theory and practice can form a high degree of unity, and students can experience the charm of innovation and entrepreneurship in practice.

\section{REFERENCES}

[1] Wang Guilin, Yang Zhiqiang. Experience and Enlightenment of Entrepreneurship Education in American and Japanese Universities. Journal of Industrial and Commercial University of Chongqing, 2014(31):P151-156. 王桂林，杨志强.美国、日本高校创业教育发展 经验及启示.重庆工商大学学报,2014(31):P151-156.

[2] Ren Luyao, Yang Zengxiong. Enterprise Education: Third Education Passport[J]. Education Research Monthly, 2010（11）. 任路瑶, 杨增 雄.创业教育：第三本教育护照[J].教育学术月刊, 2010 (11).

[3] Curriculum models and Typical Case Analysis of Entrepreneurship Education in Japanese Universities[J]. Education Exploration, 2010 （10）. 日本高校创业教育课程模式及典型个案分析[J].教育探索, 2010 (10).

[4] Shi Yongchuan. Study on the Development Course of Education in Chinese Universities[J]. China Higher Education Research, 2013 (4). 施永川.我国高校创业教育十年发展历程研究[J].中国高教研究, 2013 (4)

[5] Lu Shuhua. Research on Settings of Education Course System in Local Undergraduate Universities [D]. Chongqing University, 2012. 鲁淑华. 地方本科院校创业教育课程体系设置研究[D].重庆大学, 2012.

[6] Zhuang Yimin. Investigation and Countermeasures of Entrepreneurship Education in Local Colleges and Universities - Taking Liming Vocational University as an Example. Journal of Liming Vocational University, 2012(6):P46-51. 庄一民.地方高校创业教育现状调查及对 策-以黎民职业大学为例. 黎民职业大学学报,2012(6):P46-51.

[7] Tu Chunfei, Lu Guifang, Study on Path of innovation and Entrepreneurship Education for University Students based on Tutorial System $[\mathrm{J}]$. Journal of Ningbo University (Educational Science Edition), 2015，37(3): 116-119. 屠春飞，卢佳芳. 基于导师制的大学生创新 创业教育路径探究 [J]. 宁波大学学报(教育科学版), 2015, 37(3): 116-119.

[8] Li Qiubin. Basic Mode and Path Selection of College Students' Innovation and Entrepreneurship Education, Journal of Minjiang University, 2014(1): 118-124. 李秋斌. 大学生创新创业教育基本模 式和路径选择。闽江学院学报, 2014(1): 118-124.

[9] Li Hui, Way of College Students' Innovation and Entrepreneurship Education from the Perspective of Connotation Development [J]. Higher Education Exploration, 2013(4): 133. 136. 李辉. 内涵发展视界下的大学生创新创业教育路向 $[\mathrm{J}]$. 高教探 索, 2013(4): 133. 136.

[10] Huang Zhaoxin, Wang Zhiqiang. Study on Integration of Entrepreneurship Education and Professional Education in Colleges and Universities, Educational Research, 2013(12):P59-67. 黄兆信,王志强. 论高校创业教育与专业教育的融合.教育研究,2013(12):P59-67.

[11] Sun Yue, Xie Changfu. Research on Current Situation and Countermeasures of College Students' Entrepreneurship Education. China Foreign Trade, 2011(12):P131-132. 孙悦,解长福.高校大学生自 主创业教育现状及对策研究.中国对外经贸,2011(12):P131-132.

[12] Deng Qizhong, Zhou Zhiqiang. Problems and Countermeasures of College Students' Innovation and Entrepreneurship Education System[J] Innovation and Entrepreneurship Education, 2014(1). 邓淇中，周志强.
大学生创新创业教育体系的问题与对策 $[\mathrm{J}]$. 创新与创业教育, 2014(1)。

[13] Tang Li, Zhou Yang. Discussion on Optimization of Education System in Chinese Universities. China Academic Journal Electronic Publishing House,2016(3):P8-9. 唐力, 周㕷. 论我国高校创业教育体系优化的探 讨.China Academic Journal Electronic Publishing House,2016(3):P8-9.

[14] Liu Yushan. Predicament and Solution Strategy of Entrepreneurship Education in Chinese Universities: Based on Collaborative Innovation Journal of Guizhou Normal University, 2014(30):P69-74. 刘玉山.我国 高校创业教育的发展困境与化解策略一基于协同创新视角的考察 贵州师范学院学报,2014(30):P69-74.

[15] Sun Yue, Xie Changfu. Research on Current Situation and Countermeasures of College Students' Entrepreneurship Education. China Foreign Trade, 2011(12):P131-132. 孙悦,解长福.高校大学生自 主创业教育现状及对策研究.中国对外经贸,2011(12):P131-132.

[16] Kayne, Jay .State Entrepreneurship Policies and Programs, Kauffman Center for Entrepreneurial Leadership at the Ewing Marion Kauffman Foundation[Z].1999.

[17] Audretsch, David B. The Entrepreneurial Society. The FSF-NUTEK Award Winner Series[Z].2005. 